\title{
EVALUASI KESIAPAN KERJA MAHASISWA AKUNTANSI UNIVERSITAS NEGERI YOGYAKARTA MENGHADAPI ERA MASYARAKAT EKONOMI ASEAN (MEA) 2015
}

\author{
Tri Hanani \\ Prodi Akuntansi Universitas Negeri Yogyakarta \\ Trihanani1024@gmail.com
}

Sukirno

Staf Pengajar Jurusan P. Akuntansi Universitas Negeri Yogyakarta

\begin{abstract}
Abstrak : Evaluasi Kesiapan Kerja Mahasiswa Akuntansi Universitas Negeri Yogyakarta Menghadapi Era Masyarakat Ekonomi Asean (Mea) 2015. Penelitian ini bertujuan untuk mengetahui: (1) kesiapan kerja mahasiswa akuntansi ditinjau dari ethical competency. (2) Kesiapan kerja mahasiswa akuntansi ditinjau dari knowledge competency. (3) Kesiapan kerja mahasiswa akuntansi ditinjau dari capability competency. (4) Kesiapan kerja mahasiswa akuntansi ditinjau dari respect about human right and value. (5) Serta kesiapan kerja mahasiswa akuntansi ditinjau dari analysis competency. Penelitian ini termasuk ke dalam penelitian evaluatif. Populasi dalam penelitian ini adalah mahasiswa akuntansi UNY. Pemilihan sampel menggunakan metode purposive sampling. Berdasarkan kriteria yang telah ditentukan diperoleh sampel sebanyak 162 mahasiswa. Teknik analisis data yang digunakan adalah statistik deskriptif. Hasil dari penelitian ini menunjukkan bahwa: (1) Kesiapan kerja mahasiswa akuntansi ditinjau dari aspek ethical competency termasuk dalam kategori siap yakni (73,46\%). (2) Kesiapan kerja mahasiswa Akuntansi ditinjau dari aspek knowledge competency termasuk dalam kategori siap dengan persentase sebesar (75,93\%). (3) Kesiapan kerja ditinjau dari aspek capability competency termasuk dalam kategori siap dengan pencapaian persentase sebesar (59,26\%). (4) Kesiapan kerja ditinjau dari aspek respect about human right and value mahasiswa termasuk dalam kategori siap (67,9\%). (5) Kesiapan kerja ditinjau dari aspek analysis competency mahasiswa termasuk dalam siap, dengan pencapaian persentase sebesar $(69,14 \%)$.
\end{abstract}

Kata Kunci: Kesiapan Kerja, Mahasiswa akuntansi, Masyarakat Ekonomi ASEAN

Abstract : Work Readiness Evaluation Of Accounting Students In Yogyakarta State University In Facing Asean Economic Community (Aec) 2015. This study aims to evaluate: (1) Work Readiness accounting student at the Yogyakarta State University in terms of ethical competency. (2) Work Readiness accounting student at the Yogyakarta State University in terms of knowledge competency. (3) Work Readiness accounting student at the Yogyakarta State University in terms of capability competency. (4) Work Readiness accounting student at the Yogyakarta State University in terms of respect about human rights and value. (5) Work Readiness accounting student at the Yogyakarta State University in terms of competency analysis. This study was an evaluating research. Population in this research was 293 accounting students in Yogyakarta State University. The sample size was 162 students drawn by purposive sampling method. The data analysis technique used was descriptive statistics. Results of this study indicate that: (1) work readiness of accounting student in Yogyakarta State University in terms with ethical aspects of the competency is categorized as ready (73.46\%). (2) Work readiness of accounting student in Yogyakarta State University review of aspects of knowledge competency is categorized as ready (75.93\%). (3) Work readiness in term capability competency is categorized as ready (59.26\%). (4) Work readiness in terms of aspects about human rights respect and value is categorized as ready (67.9\%). (5) Work readiness in terms of analysis competency is categorized as ready (69.14\%).

Keywords: Work Readiness, accounting student, ASEAN Economic Community 


\section{JURNAL NOMINAL / VOLUME V NOMOR 1 / TAHUN 2016}

\section{PENDAHULUAN}

Perdagangan dan kerja sama antar negara merupakan salah satu kegiatan pokok perekonomian dunia. Sebuah negara tidak dapat berkembang tanpa adanya interaksi perdagangan dengan negara lain. Indonesia sebagai salah satu negara di dunia ini tidak dapat menghindar dari kegiatan perdagangan antarnegara disebabkan adanya kebutuhan-kebutuhan yang belum dapat dipenuhi sendiri. ASEAN sebagai wadah kerjasama antar negara di regional ASEAN termasuk Indonesia, salah satunya menghasilkan kesepakatan untuk membentuk Masyarakat Ekonomi ASEAN pada 2015.

Masyarakat Ekonomi ASEAN (MEA) pada 2015 bertujuan untuk meningkatkan kemakmuran, daya saing dan integrasi ekonomi negara ASEAN dalam ekonomi global. Untuk mewujudkan MEA pada tahun 2015, seluruh negara ASEAN termasuk Indonesia harus melakukan liberalisasi perdagangan barang, jasa, investasi, tenaga kerja terampil secara bebas dan arus modal yang lebih bebas. Akuntan merupakan salah satu profesi yang akan terkena dampak dari pelaksanaan MEA 2015 karena termasuk dalam tenaga kerja terampil.

Hingga tahun 2009, telah dihasilkan beberapa MRA (Mutual Recognition
Arrangement) yang mendukung upaya pelaksanaan masyarakat ekonomi ASEAN 2015. MRA ini yang akan menjadi pedoman penciptaan prosedur dan mekanisme untuk mengakui kesetaraann pendidikan, pelatihan, pengalaman dan persyaratan lisensi untuk penyedia jasa professional beroperasi. MRA tersebut meliputi untuk penyediaan jasa engineering, nursing, architectural, surveying qualification, tenaga medis (dokter umum dan dokter gigi), dan jasa akuntansi. Pelaksanaan arus bebas tenaga kerja akuntansi.tertuang dalam ASEAN MRA Framework on Accountancy Services yang telah sah ditandatangani oleh para menteri keuangan ASEAN pada 26 Februari 2009 di Thailand. Dengan penandatanganan MRA tersebut dapat dipastikan setelah 2015 akan banyak tenaga akuntan dari negara-negara ASEAN yang berpraktek di Indonesia.

Dengan diberlakukannya hal tersebut seharusnya calon akuntan Indonesia siap bersanding dan bersaing dengan akuntan dari negara ASEAN yang lain. Namun menilik kondisi Indonesia saat ini lulusan perguruan tinggi masih cukup besar dalam menyumbang angka pengangguran. Berdasarkan data dari BPS pada Februari 2013 lulusan perguruan tinggi menyumbang angka 5,04\% dari jumlah pengangguran terbuka menurut jenjang 


\section{JURNAL NOMINAL / VOLUME V NOMOR 1 / TAHUN 2016}

pendidikan yang ditamatkan sejumlah 360.000. Banyaknya pengangguran terdidik lulusan perguruan tinggi di Indonesia mengindikasikan kekurangsiapan mahasiswa dalam memasuki dunia kerja, termasuk mahasiswa akuntansi.

Menilik tingkat pertumbuhan akuntan professional di Indonesia dari tahun 2010 hingga 2014 baru berkisar pada angka 3\%. Lulusan program studi akuntansi dari perguruan tinggi se-Indonesia pada tahun 2010 mencapai 35.304 lulusan. Jumlah ini meningkat drastis dari tahun sebelumnya yang hanya mencapai 24.402 lulusan (IAI,2014). Idealnya meningkatnya jumlah lulusan akuntansi di Indonesia harusnya mampu mendukung peningkatan pada jumlah akuntan professional pula.

Hal di atas sungguh ironis bila dibandingkan dengan besarnya peluang menjadi akuntan di Indonesia. Tenaga akuntan di Indonesia, sebenarnya masih memiliki peluang yang besar untuk berkarir di Indonesia. Jumlah penduduk Indonesia yang mencapai lebih dari 230.000.000 jiwa, sedangkan akuntan beregister yang telah menjadi anggota IAI di Indonesia baru 15.940 orang. Padahal kebutuhan akuntan professional Indonesia pada 2015 idealnya berjumlah 425.000 orang (IAI, 2014). Hal tersebut cukup kuat untuk dijadikan bukti bila peluang profesi akuntan masih terbuka lebar di Indonesia.
Perlunya studi terkait dengan kesiapan kerja mahasiswa akuntansi Indonesia juga di dukung dengan data dari IAI yang menunjukan minimnya jumlah tenaga akuntan dibanding dengan negara ASEAN lainya. Jumlah akuntan beregister di Indonesia baru berkisar pada angka 15.940. Jumlah tersebut jauh di bawah Malaysia yang memiliki 30.236 akuntan, Filipina 19.573 akuntan, Singapura 27.394 akuntan dan 56.125 akuntan. Padalah jumlah organisasi yang masih memerlukan opini laporan wajar tanpa pengecualian mencapai 226.780 (IAI,2014). Dengan dierlakukanya MEA tertanggal 31 Desember 2015 kelak hal tersebut tidak hanya menjadi ladang peluang bagi akuntan Indonesia, namun juga ladang kesempatan berkarier akuntan beregister dari negara asing khusunya dari negara ASEAN. Sehingga penting diadakan evaluasi untuk mengukur kesiapan mahasiswa akuntansi memasuki lapangan pekerjaan agar dapat diambil langkah-langkah prefentif untuk menyempurnakan kualitas lulusan.

Universitas Negeri Yogyakarta dipilih menjadi tempat penelitian mengingat lembaga perguruan tinggi tersebut telah berdiri sejak 21 Mei 1964 serta mencanangkan visi sebagai World Class University sejak 2008. Universitas Negeri Yogyakarta dirasa sangat tepat mewakili kondisi perguruan tinggi di Indonesia lainya karena telah mendapatkan sertifikasi 


\section{JURNAL NOMINAL / VOLUME V NOMOR 1 / TAHUN 2016}

terhadap kegiatan manajemen, proses dan fasilitas pendukung diantaranya Standar manajemen Mutu (SMM) International Organization for standardization (ISO) 9001:2008.

Masyarakat Ekonomi ASEAN yang akan dimulai pada 31 Desember 2015 merupakan salah satu tantangan dunia global yang harus dihadapi dunia pendidikan termasuk civitas Akuntansi Universitas Negeri Yogyakarta. Berdasarkan observasi yang dilakukan terhadap 15 mahasiswa akuntansi angkatan 2012 didapati terdapat 2 mahasiswa yang masih belum memiliki pengetahuan terkait pelaksanaan dan akibat dari MEA.

Dengan mengumpulkan data yang mendalam melalui kuesioner, peneliti berharap mendapatkan informasi yang relevan mengenai kesiapan kerja para mahasiswa akuntansi yang merupakan calon akuntan Indonesia. Disamping karena data jumlah pengangguran dari jenjang perguruan tinggi yang memprihatinkan, alasan lain dilakukannya penelitian ini adalah belum adanya jurnal nasional pada situs web google scholar mengenai evaluasi kesiapan kerja mahasiswa khususnya bidang akuntansi Indonesia terhadap rencana pelaksanaan Masyarakat Ekonomi ASEAN (MEA) 2015 di Universitas Negeri Yogyakarta. Berdasarkan latar belakang masalah diatas maka penelitian ini bertujuan untuk mengetahui Kesiapan
Kerja mahasiswa program studi akuntansi Universitas Negeri Yogyakarta menghadapai era Masyarakat Ekonomi ASEAN (MEA) 2015 ditinjau dari ethical competency, knowledge competency, capability competency, respect about human right and value dan analysis competency.

\section{METODE PENELITIAN}

Penelitian ini merupakan penelitian evaluatif dengan pendekatan deskriptif kuantitatif. Penelitian evaluatif menurut Wirawan (2011:8) adalah suatu penelitian yang dilakukan bertujuan untuk mengumpulkan informasi yang bermanfaat mengenai objek evaluasi yang dibandingkan dan dinilai dengan indikator tertentu.

Populasi dalam penelitian ini adalah Mahasiswa S1 program studi Akuntansi Universitas Negeri Yogyakarta. Teknik penentuan sampel menggunakan teknik purposive sampling. Jumlah populasi mahasiswa Akuntansi FE UNY adalah 293 mahasiswa yang dibulatkan ke atas menjadi 300 mahasiswa. Berdasarkan Tabel Isaac dan Michael (Sugiyono, 2010:71) dengan taraf kesalahan 5\%, maka sampel yang diambil adalah 162 mahasiswa.

Data yang digunakan dalam penelitian ini adalah data primer. Peneliti menggunakan teknik kuesioner (angket) dalam mengumpulkan data. Hal tersebut karena 
JURNAL NOMINAL / VOLUME V NOMOR 1 / TAHUN 2016

kuesioner mampu menghasilkan data primer langsung dari subjek penelitian.

Dari berbagai teori dan penelitian terdahulu mengenai kesiapan kerja, peneliti dalam penelitian ini menggunakan indikator yang digunakan oleh Muttanachai Suttipun (2014) yang dimodifikasi yang terdiri dari ethical competency, knowledge competency, capability competency, respect about human right and value dan analysis competency. Aspek-aspek Kesiapan Kerja tersebut dijabarkan ke dalam indikator-indikator berikut:

Tabel 1. Kisi-Kisi Instrumen Penelitian

\begin{tabular}{ll}
\hline Ethical & Moral dan etika akuntan \\
\cline { 2 - 2 } competency & Tanggung jawab \\
\cline { 2 - 2 } & Kemampuan mengendalikan \\
& emosi \\
\hline
\end{tabular}

Tidak keberpihakan

\begin{tabular}{ll}
\hline Knowledge & Pengetahuan tentang IFRS \\
\cline { 2 - 2 } competency & Pengetahuan tentang profesi \\
& akuntan. \\
\cline { 2 - 2 } & Pengetahuan tentang MEA \\
\cline { 2 - 2 } & Pengetahuan tentang \\
& manajemen perubahan \\
\hline Capability & Persepsi tentang persaingan \\
competency & akuntan di ASEAN \\
\cline { 2 - 2 } & Persepsi keahlian negosiasi \\
\cline { 2 - 2 } & Persepsi isu politik terkait \\
& negara anggota ASEAN \\
\cline { 2 - 2 } & Persepsi standar akuntansi \\
& di berbagai negara ASEAN
\end{tabular}

\begin{tabular}{|c|c|}
\hline Respect & Kebahagiaan kerja \\
\hline $\begin{array}{l}\text { about } \\
\text { human }\end{array}$ & $\begin{array}{l}\text { Kemampuan bekerjasama } \\
\text { dalam tim }\end{array}$ \\
\hline $\begin{array}{l}\text { right and } \\
\text { value }\end{array}$ & $\begin{array}{l}\text { Pengetahuan budaya negara } \\
\text { anggota ASEAN }\end{array}$ \\
\hline & $\begin{array}{l}\text { Toleransi terhadap } \\
\text { perbedaan suku, ras, agama } \\
\text { dan kewarganegaraan. }\end{array}$ \\
\hline $\begin{array}{l}\text { Analysis } \\
\text { competency }\end{array}$ & $\begin{array}{l}\text { Kemampuan berbahasa } \\
\text { Inggris }\end{array}$ \\
\hline & $\begin{array}{l}\text { Kemampuan berbahasa } \\
\text { negara anggota ASEAN }\end{array}$ \\
\hline & $\begin{array}{l}\text { Penguasaan } \\
\text { komunikasi }\end{array}$ \\
\hline & $\begin{array}{l}\text { Penguasaan perangkat lunak } \\
\text { akuntansi }\end{array}$ \\
\hline
\end{tabular}

Pengujian validitas dalam penelitian ini menggunakan metode analisis faktor eksploratori. Analisis faktor eksploratori menggunakan matriks korelasi meliputi uji Kaiser Meyer Oikin (KMO) mengenai MSA (Measure of Sampling Adequacy) dan Uji Bartlett. Menurut J.F Hair (2006:115) sekelompok data dikatakan memenuhi asumsi kecukupan data jika nilai MSA (Measure of Sampling Adequacy) dan KMO lebih besar daripada 0,5. Dari hasil diatas uji MSA KMO mencapai angka 0,762.

Hasil uji Barlett dengan SPSS menunjukkan bahwa antar variabel pada kesiapan kerja telah memenuhi asumsi saling berkorelasi yaitu dengan melihat nilai Sig. 
0.000 kurang dari $\alpha 0.05$ yang berarti tolak matriks korelasi bukan mastriks identitas. Dengan demikian kedua asumsi untuk analisis faktor telah terpenuhi.

Langkah selanjutnya adalah mencari nilai MSA pada tabel anti image correlation (AIC) dimana faktor yang lolos harus memiliki nilai MSA diatas 0,5. Item pertanyaan $\mathrm{K} 4, \mathrm{~K} 7, \mathrm{C} 6, \mathrm{C} 3, \mathrm{C} 9$ dan $\mathrm{A} 4$ memiliki nilai MSA dibawah 0,5 sehingga tidak diikutsertakan lagi dalam analisis karena dinilai kurang valid.

Selanjutnya, pada tabel total variance explained dari 41 butir yang dimasukkan ke dalam analisis faktor didapatkan nilai akar karakteristik (eigen values) di atas 1 ada sebanyak 13 faktor, lebih banyak dari teori, yaitu 5 faktor. Setelah dikeluarkan 19 butir sehingga jumlah butir yang tinggal ada sebanyak 22 butir, dan dianalisis kembali.

Tabel 2. Hasil Uji KMO dan Barlett Setelah Eliminasi

\begin{tabular}{llr}
\hline & Kaiser-Meyer- & 0,816 \\
& Olkin Measure & \\
& of Sampling & \\
& Adequacy. & \\
\hline Bartlett's & Approx. Chi- & 1436,39 \\
Test of & Square & 5 \\
Sphericity & df & 231 \\
\cline { 2 - 3 } & Sig. & 0,000
\end{tabular}

Sumber : Data primer yang diolah 2015
Pada rotated component matrix, menunjukkan tidak ada butir yang melewati muatan faktor "cut off point" <0,30. Muatan faktor terbesar terdapat pada butir C7 sebesar 0,846 dan terkecil butir R6 sebesar 0,445. Dengan demikian 22 butir pernyataan adalah valid. Hasil analisis faktor setelah dilakukan rotasi varimax sebanyak 25 kali menunjukkan bahwa instrument evaluasi kesiapan kerja mahasiswa akuntansi memiliki sebaran sebagai berikut :

Tabel 3. Sebaran Muatan Faktor Setelah Dirotasi

\begin{tabular}{cll}
\hline Faktor & \multicolumn{1}{c}{$\begin{array}{c}\text { Sebaran } \\
\text { butir }\end{array}$} & \multicolumn{1}{c}{ Nama Faktor } \\
& R2, R1, E5, & Ethical \\
& R3, R4, E6, & competency \\
& A7, R6 & \\
\hline $\mathbf{2}$ & R7, R8, A5, & Knowledge \\
& A6 & competency \\
\hline $\mathbf{3}$ & E2, E1, E3, & Capability \\
& E4 & competency \\
4 & E8, E7, C5, & Respect about \\
& C4 & human right and \\
& & value \\
\hline $\mathbf{5}$ & C7, C8 & Analysis \\
& & competency \\
\hline
\end{tabular}




\section{JURNAL NOMINAL / VOLUME V NOMOR 1 / TAHUN 2016}

Tabel 4. Hasil Eigen Values Setelah Eliminasi

\begin{tabular}{cccc}
\hline Com & \multicolumn{3}{c}{ Extraction Sums of Squared } \\
pone & \multicolumn{3}{c}{ Loadings } \\
\cline { 2 - 4 } $\boldsymbol{n t}$ & Total & \% of & Cumulativ \\
& & Variance & $e \%$ \\
\hline $\mathbf{1}$ & 6,731 & 30,595 & 30,595 \\
\hline $\mathbf{2}$ & 2,021 & 9,185 & 39,780 \\
\hline $\mathbf{3}$ & 1,929 & 8,767 & 48,547 \\
\hline $\mathbf{4}$ & 1,391 & 6,322 & 54,869 \\
\hline $\mathbf{5}$ & 1,079 & 4,904 & 59,774 \\
\hline
\end{tabular}

Sumber : Data primer yang diolah 2015

Dari hasil analisis tersebut, dapat diketahui bahwa secara umum butir-butir instrument yang dikembangkan dapat mengukur kesiapan kerja mahasiswa akuntansi sebesar 59,774\%. Hal ini berarti belum dapat melampaui standar kumulatif minimal yakni $60 \%$.

Analisis data dalam penelitian ini dilakukan setelah semua data terkumpul. Menurut Suharsimi Arikunto (2013:191) langkah-langkah analisis data yang berlaku yaitu: persiapan, tabulasi dan penerapan data.

Langkah persiapan dilakukan untuk mengecek responden, pengecekan kelengkapan pengisian dan pengecekan lainya yang bertujuan supaya data yang terkumpul dapat maksimal. Tabulasi yang dilakukan meliputi scoring dan coding. Scoring penelitian ini menggunakan skala likert modifikasi dalam skala tersebut jawaban pertanyaan positif yang diberikan mahasiswa $\mathrm{SS}=4, \mathrm{~S}=3, \mathrm{TS}=2$ dan $\mathrm{STS}=1$. Sedangkan untuk pertanyaan negatif adalah $\mathrm{SS}=1, \mathrm{~S}=2, \mathrm{TS}=3$ dan $\mathrm{STS}=4$.

Analisis data penelitian ini dilakukan dengan metode deskriptif. Untuk mengetahui Kesiapan Kerja Mahasiswa Program Studi Akuntansi Universitas Negeri Yogyakarta digunakan teknik analisis deskriptif dengan kriteria ideal dan standar deviasi ideal. Rumus yang digunakan adalah sebagai berikut:

$\mathrm{Mi}=1 / 2(\mathrm{ST}+\mathrm{SR}) \quad \mathrm{DSi}=1 / 6(\mathrm{ST}-\mathrm{SR})$

(Sumber: Sutrisno Hadi, 2001:263)

Keterangan :

$$
\begin{aligned}
& \mathrm{Mi}=\text { mean ideal } \\
& \text { DSi }=\text { deviasi standar ideal } \\
& \mathrm{ST}=\text { skor tertinggi } \\
& \mathrm{SR}=\text { skor terendah }
\end{aligned}
$$

Skor ideal tertinggi dan skor ideal terendah diperoleh dari penjumlahan skor masing-masing variabel. Skor terendah tiap butir pertanyaan 1 dan skor tertinggi 4 . Penarikan kesimpulan menggunakan metode rata-rata dan standar deviasi ideal kemudian dikategorikan seperti pada tabel berikut: 
Tabel 5. Kategorisasi Kesiapan Kerja Mahasiswa

\begin{tabular}{lll}
\hline No & Kategori & \multicolumn{1}{c}{ Rentang } \\
\hline 1. & Sangat Siap & $\geq \mathrm{Mi}+(1,5 \mathrm{x} \mathrm{DSi})$ \\
\hline 2. & Siap & $\mathrm{Mi} \leq \mathrm{x}<\mathrm{Mi}+$ \\
& & $(1,5 \mathrm{x} \mathrm{Dsi})$ \\
\hline 3. & Kurang Siap & $\mathrm{Mi}-(1,5 \mathrm{x} \mathrm{Dsi}) \leq$ \\
& & $\mathrm{x}<\mathrm{Mi}$ \\
\hline 4. & Sangat tidak & $\mathrm{x}<\mathrm{Mi}-1,5(\mathrm{SDi})$ \\
& siap & \\
\hline
\end{tabular}

(Sumber: Suharsimi Arikunto, 2013:263)

HASIL PENELITIAN DAN

\section{PEMBAHASAN}

Responden yang digunakan dalam penelitian ini adalah mahasiswa program studi Akuntansi Unversitas Negeri Yogyakarta. Kuesioner yang disebar peneliti sebanyak 177 buah yang didistribusikan kepada mahasiswa akuntansi angkatan 2012 sebanyak 68, angkatan 2013 sebanyak 52 dan angkatan 2014 sebanyak 57 buah. Tingkat pengembalian (responsive rate) sebesar 91,53\% dikarenakan 8 kuesioner tidak kembali dan 7 kuesioner tidak diisi lengkap.

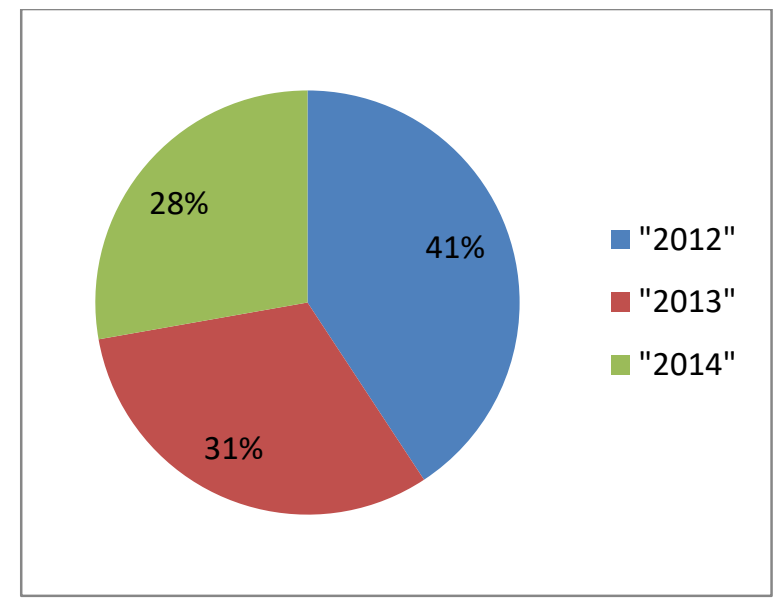

Gambar 1. Persentase Karakteristik Responden Berdasarkan Tahun Masuk

Gambar 1 menunjukkan persentase responden pada penelitian ini. Responden dalam penelitian ini sebagian besar berasal dari angkatan 2012 yakni sebanyak 66 mahasiswa sedangkan responden yang berasal dari angkatan 2013 sebanyak 51 mahasiswa dan angkatan 2014 sebanyak 45 mahasiswa.

Deskripsi data penelitian meliputi nilai Mean (M), Median (Me), Modus (Mo), Standar Deviasi (SD), frekuensi data, Diagram Batang penelitian dari variabel kesiapan kerja yang dibagi kedalam lima indikator. Data yang digunakan untuk mengetahui kesiapan kerja mahasiswa akuntansi UNY dalam penelitian ini diperoleh melalui angket dengan jumlah item sebanyak 41 butir. Hasil analisis variabel kesiapan kerja dapat dilihat pada tabel berikut : 
Tabel 6. Deskripsi Data

\begin{tabular}{llc}
\hline & \multicolumn{1}{c}{ Ukuran } & Nilai \\
\hline $\mathbf{1}$ & Jumlah $(\mathrm{N})$ & 162 \\
\hline $\mathbf{2}$ & Mean $(\mathrm{M})$ & 114 \\
\hline $\mathbf{3}$ & Median $(\mathrm{Me})$ & 113 \\
\hline $\mathbf{4}$ & Modus (Mo) & 107 \\
\hline $\mathbf{5}$ & Standar Deviasi (SD) & 9,14 \\
\hline $\mathbf{6}$ & Skor minimum (Min) & 90 \\
\hline $\mathbf{7}$ & Skor maksimum & 141 \\
& (Max) &
\end{tabular}

Sumber : data primer yang telah diolah

Berdasarkan rata-rata dan standar deviasi ideal dapat diidentifikasi kecenderungan tingkat kesiapan kerja mahasiswa akuntansi dilihat dari kompetensi etika adalah sebagai berikut :

Tabel 7. Kecenderungan Ethical Competency Mahasiswa Program Studi Akuntansi UNY

\begin{tabular}{llll}
\hline No & Kategori & Rentang & Jumlah \\
\hline $\mathbf{1}$ & Sangat Siap & $\geq 26$ & 41 \\
\hline $\mathbf{2}$ & Siap & $20-25$ & 119 \\
\hline $\mathbf{3}$ & Kurang Siap & $14-19$ & 2 \\
\hline $\mathbf{4}$ & Sangat Tidak & $<14$ & 0 \\
& Siap & &
\end{tabular}

Sebagian besar mahasiswa akuntansi Universitas Negeri Yogyakarta merasa memliki kesiapan kerja pada posisi siap untuk menghadapi era Masyarakat Ekonomi ASEAN yakni dengan persentase sebanyak
$73,46 \%$. Mahasiswa yang berpersepsi sangat siap sebanyak $25,31 \%$. Sedangkan sebanyak 1,23\% mahasiswa berpersepsi bahwa kurang siap kerja pada era Masyarakat Ekonomi ASEAN

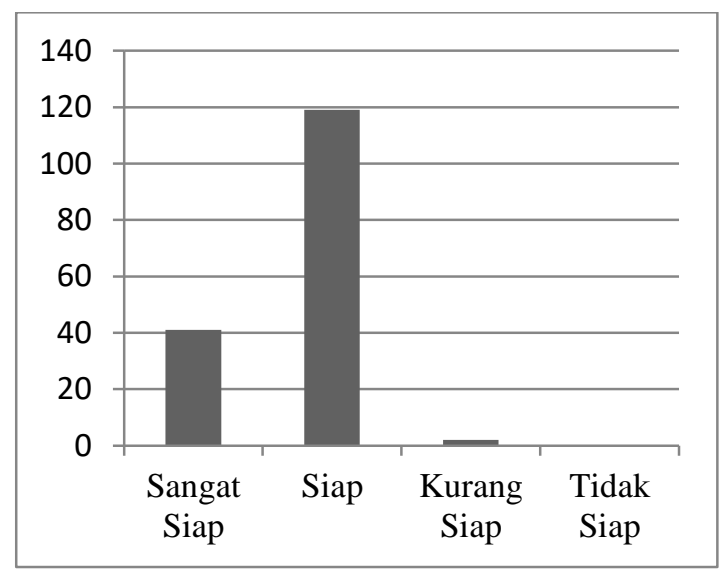

Gambar 2. Diagram Batang Kecenderungan Ethical Competency Mahasiswa Akuntansi UNY

Berdasarkan analisis ini dapat disimpulkan bahwa ditinjau dari dimensi ethical competency sebagian besar $(73,46 \%)$ Mahasiswa Program Studi Akuntansi UNY merasa memiliki Kesiapan Kerja pada era MEA pada kategori siap. Mahasiswa Program Studi Akuntansi UNY tersebut dapat ditelusuri ke dalam empat dimensi yakni moral dan etika akuntan, tanggung jawab, kemampuan mengendalikan emosi dan ketidakberpihakan. Secara lebih rinci ke empat dimensi indikator ethical competency tersebut dapat ditelusuri tingkat perananya terhadap Kesiapan Kerja Mahasiswa Program Studi Akuntansi UNY dengan rata- 


\section{JURNAL NOMINAL / VOLUME V NOMOR 1 / TAHUN 2016}

rata skor dan deviasi standar skor pada tabel berikut:

Tabel 8. Perbandingan Mean dan Standar Deviasi Masing-Masing Indikator Ethical Competency

\begin{tabular}{|c|c|c|}
\hline Kompetensi & Mean & Ranking \\
\hline Ethical competency & 3,04 & \\
\hline $\begin{array}{l}\text { Moral dan etika } \\
\text { akuntan }\end{array}$ & 3,25 & 1 \\
\hline $\begin{array}{l}\text { Tanggung jawab } \\
\text { mahasiswa }\end{array}$ & 3,05 & 2 \\
\hline $\begin{array}{l}\text { Kemampuan } \\
\text { mengendalikan } \\
\text { emosi }\end{array}$ & 2,84 & 4 \\
\hline Ketidakberpihakan & 3,03 & 3 \\
\hline
\end{tabular}

Tabel 8 mengindikasikan bila mahasiswa akuntansi Universitas Negeri Yogyakarta telah memiliki kompetensi yang tinggi dalam hal moral, etika, tanggung jawab dan ketidakberpihakan. Rerata skor dimensi kemampuan mengendalikan emosi mendapat nilai terendah yakni 2,84 akan tetapi skor tersebut masih berada pada tingkat yang baik mengingat skala likert yang digunakan hanya berkisar 1-4.

Untuk mengidentifikasi kecenderungan tinggi rendahnya skor Kesiapan Kerja Mahasiswa Program Studi Akuntansi Universitas Negeri Yogyakarta dengan menggunakan skor ideal terendah dan skor ideal tertinggi. Dari nilai-nilai tersebut digunakan untuk perhitungan kategorisasi ke dalam 4 kelompok kriteria kecenderungan yaitu tidak siap, kurang siap, siap dan sangat siap. Adapun hasil perhitungan kategori kecenderungan Kesiapan Kerja Mahasiswa Program Studi Akuntansi Universitas Negeri Yogyakarta dapat dilihat pada tabel berikut:

Tabel 9. Kecenderungan Knowledge Competency Mahasiswa Program Studi Akuntansi UNY

\begin{tabular}{llcc}
\hline No & Kategori & Rentang & Jumlah \\
\hline $\mathbf{1}$ & Sangat Siap & $\geq 26$ & 6 \\
\hline $\mathbf{2}$ & Siap & $20-25$ & 123 \\
\hline $\mathbf{3}$ & Kurang Siap & $14-19$ & 33 \\
\hline $\mathbf{4}$ & Sangat Tidak & $<14$ & 0 \\
& Siap & & \\
\hline
\end{tabular}

Berdasarkan tabel 21, dari keseluruhan data sampel diketahui sebagian besar Mahasiswa Program Studi Akuntansi UNY yaitu sebanyak 123 mahasiswa. Deskripsi data tersebut dapat dilihat dengan lebih jelas pada gambar 3 berikut : 


\section{JURNAL NOMINAL / VOLUME V NOMOR 1 / TAHUN 2016}

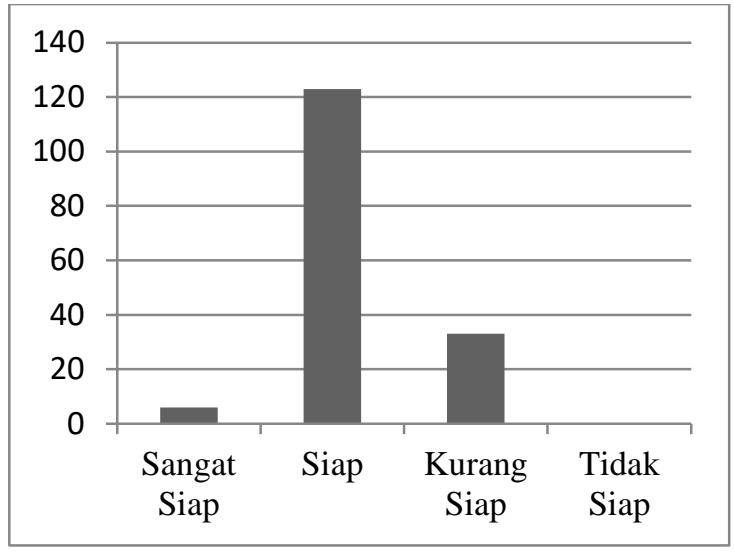

Gambar 3. Diagram Batang Kecenderungan Knowledge Competency Mahasiswa Akuntansi UNY

Berdasarkan gambar diatas dapat disimpulkan bahwa dilihat dari dimensi kompetensi pengetahuan sebagian besar $(75,93 \%)$ mahasiswa akuntansi FE UNY merasa memiliki kesiapan kerja pada era MEA. Sedangkan hanya 33 mahasiswa yang berada dalam kategori kurang siap dengan prosentase sebesar 20,37\%.

Kesiapan kerja mahasiswa akuntansi tersebut dapat ditelusuri ke dalam empat dimensi yakni pengetahuan terkait IFRS (International Financial Reporting Standard), pengetahuan terkait profesi akuntan, pengetahuan tentang MEA dan pengetahuan tentang manajemen perubahan.

Rerata skor terendah didapati pada aspek pengetahuan terkait profesi akuntan yang artinya perlu adanya usaha dari pihak penyelenggara pendidikan untuk meningkatkan pengetahuan mahasiswa pada aspek tersebut. Walau begitu secara umum, kesiapan kerja mahasiswa akuntansi
Universitas Negeri Yogyakarta berada pada kategori siap ditinjau dari kompetensi pengetahuan.

Tabel 10. Perbandingan Mean dan Standar Deviasi Masing-Masing Indikator Knowledge Competency

\begin{tabular}{lcc}
\hline \multicolumn{1}{c}{ Kompetensi } & Mean & Ranking \\
\hline $\begin{array}{l}\text { Knowledge } \\
\text { competency }\end{array}$ & 2,67 & \\
\hline $\begin{array}{l}\text { Pengetahuan } \\
\text { tentang IFRS }\end{array}$ & 2,74 & 2 \\
\hline $\begin{array}{l}\text { Pengetahuan } \\
\text { tentang profesi } \\
\text { akuntan }\end{array}$ & \\
\hline $\begin{array}{l}\text { Pengentahuan } \\
\text { tentang MEA }\end{array}$ & 2,63 & \\
\hline Pengetahuan & \\
tentang & 2,85 & \\
manajemen & & \\
perubahan & & \\
\hline
\end{tabular}

Rerata skor terendah didapati pada aspek pengetahuan terkait profesi akuntan yang artinya perlu adanya usaha dari pihak penyelenggara pendidikan untuk meningkatkan pengetahuan mahasiswa pada aspek tersebut. Walau begitu secara umum, Kesiapan Kerja mahasiswa akuntansi Universitas Negeri Yogyakarta berada pada kategori siap ditinjau dari knowledge competency.

Capability Competency meliputi empat aspek yaitu persepsi tentang persaingan 


\section{JURNAL NOMINAL / VOLUME V NOMOR 1 / TAHUN 2016}

akuntan di ASEAN, persepsi keahlian negosiasi, persepsi isu politik dan yang terakhir persepsi standar akuntansi di berbagai negara ASEAN. Berikut hasil perhitungan kecenderungan kesiapan kerja mahasiswa program studi akuntansi UNY ditinjau dari capability competency:

Tabel 11. Kecenderungan Capability Competency Mahasiswa Program Studi Akuntansi UNY

\begin{tabular}{llcc}
\hline No & Kategori & Rentang & Jumlah \\
\hline $\mathbf{1}$ & Sangat Siap & $\geq 29,25$ & 4 \\
\hline $\mathbf{2}$ & Siap & $22,5-$ & 96 \\
& & 29,24 & \\
& & $15,75-$ & 62 \\
$\mathbf{3}$ & Kurang & 22,4 & \\
& Siap & $<15,75$ & 0 \\
\hline $\mathbf{4}$ & Sangat & & \\
& Tidak Siap & &
\end{tabular}

Adapun hasil perhitungan kategori kecenderungan kesiapan kerja mahasiswa akuntansi Universitas Negeri Yogyakarta dapat dilihat pada gambar berikut:

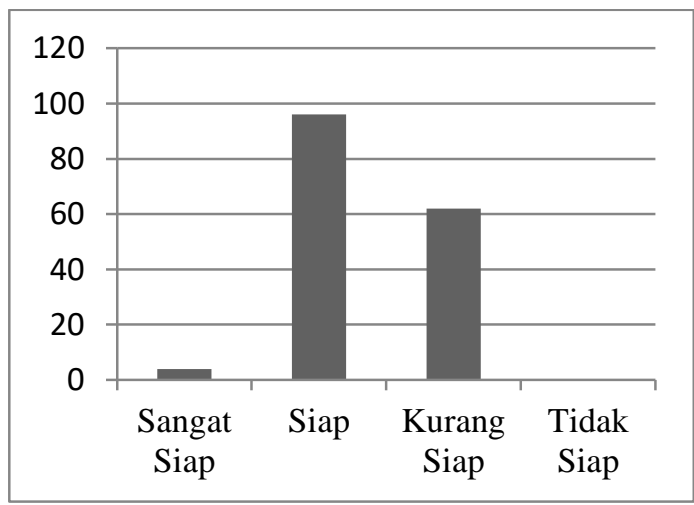

Gambar 4. Diagram Batang
Kecenderungan Capability Competency

Mahasiswa Akuntansi UNY

Keseluruhan data sampel diketahui sebagian besar jumlah mahasiswa yaitu sebanyak 96 siswa, mengatakan bahwa pada kategori siap. Sedangkan sisanya yaitu 62 siswa menyatakan kompetensi kemampuan dalam kategori kurang siap dengan persentase sebesar 38,27 \% dan hanya 2,47\% mahasiswa yang masuk pada kategori sangat siap.

Tabel 12. Perbandingan Mean dan Standar Deviasi Masing-Masing Indikator Capability Competency

\begin{tabular}{|c|c|c|}
\hline Kompetensi & Mean & Ranking \\
\hline Capability competency & 2,61 & \\
\hline $\begin{array}{ll}\text { Persepsi } & \text { tentang } \\
\text { persaingan } & \text { akuntan } \\
\text { di ASEAN } & \end{array}$ & 2,86 & 3 \\
\hline $\begin{array}{l}\text { Persepsi keahlian } \\
\text { negosiasi }\end{array}$ & 2,91 & 4 \\
\hline $\begin{array}{l}\text { Persepsi isu politik } \\
\text { terkait } \\
\text { anggota ASEAN }\end{array}$ & 2,33 & 2 \\
\hline $\begin{array}{lr}\text { Persepsi } & \text { standar } \\
\text { akuntansi di negara } \\
\text { ASEAN }\end{array}$ & 2,19 & 1 \\
\hline
\end{tabular}

Tabel di atas mengindikasikan bila mahasiswa akuntansi Universitas Negeri Yogyakarta telah memiliki pemahaman terkait persaingan akuntan dan keahlian 


\section{JURNAL NOMINAL / VOLUME V NOMOR 1 / TAHUN 2016}

negosiasi. Selain itu mahasiswa juga telah memiliki pengatahuan terkait isu politik dan standar akuntansi. Rerata skor dimensi persepsi standar akuntansi di berbagai negara ASEAN mendapat nilai terendah yakni 2,19 akan tetapi skor tersebut masih berada pada tingkat yang baik bila dibandingkan dengan skala likert yang digunakan.

Berdasarkan rata-rata dan standar deviasi ideal dapat diidentifikasi kecenderungan tingkat kesiapan kerja mahasiswa akuntansi dilihat dari respect about human right and value yang dimiliki mahasiswa akuntansi Universitas Negeri Yogyakarta adalah sebagai berikut

Tabel 13. Kecenderungan Respect About Human Right and Value Mahasiswa Program Studi Akuntansi UNY

\begin{tabular}{|l|l|c|c|}
\hline No & Kategori & Rentang & Jumlah \\
\hline 1 & Sangat Siap & $\geq 26$ & 50 \\
\hline 2 & Siap & $20-25$ & 110 \\
\hline 3 & Kurang Siap & $14-19$ & 2 \\
\hline 4 & $\begin{array}{l}\text { Sangat } \\
\text { Tidak Siap }\end{array}$ & $<14$ & 0 \\
\hline
\end{tabular}

Berdasarkan gambar di atas dapat disimpulkan bahwa sebagian besar $(67,9 \%)$ mahasiswa merasa siap, mahasiswa yang merasa sangat siap sebanyak 30,86\%, sebagian kecil merasa kurang siap yaitu sebesar $1,23 \%$ dan $0 \%$ mahasiswa akuntansi
FE UNY yang merasa sangat tidak siap terhadap Masyarakat Ekonomi ASEAN.

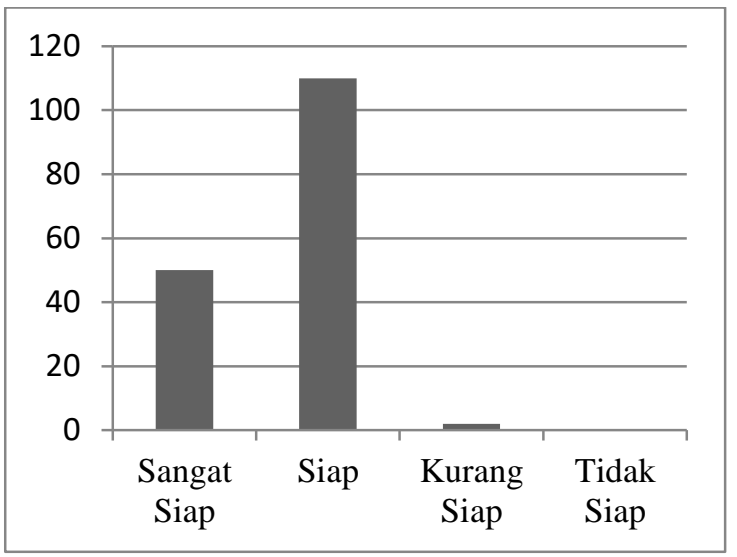

Gambar 5. Diagram Batang Kecenderungan Respect About Human Right and Value Mahasiswa Akuntansi UNY

Berdasarkan analisis ini dapat disimpulkan bahwa sebagian besar $(67,9 \%)$ mahasiswa Mahasiswa Program Studi Akuntansi UNY merasa siap terhadap MEA diukur dari aspek kepedulian pada nilai dan hak kemanusiaan. Aspek kepedulian pada nilai dan hak kemanusiaan diukur melalui empat hal yakni kebahagiaan kerja, kemampuan bekerjasama dalam tim, pengetahuan budaya, dan toleransi. Secara lebih rinci berikut rerata dan standar deviasi skor masing-masing aspek pada aspek kepedulian pada nilai dan hak kemanusiaan 


\section{JURNAL NOMINAL / VOLUME V NOMOR 1 / TAHUN 2016}

Tabel 14. Perbandingan Mean dan Standar Deviasi Masing-Masing Indikator Respect About Human Right and Value

\begin{tabular}{lcc}
\hline \multicolumn{1}{c}{ Kompetensi } & Mean & Ranking \\
Respect about & 3,09 & \\
human right and & & \\
value & & \\
\hline Kebahagiaan & 3,15 & 2 \\
kerja & & \\
\hline Kemampuan & 3,06 & 3 \\
bekerja sama & & \\
dalam tim & & \\
\hline Pengetahuan & 2,78 & 4 \\
budaya negara & \\
anggota ASEAN & \\
\hline Toleransi \\
terhadap \\
perbedaan SARA
\end{tabular}

Apabila dirunut ke rerata skor tiap indikator, skor terendah yakni 2,78 diperoleh oleh aspek pengetahuan budaya negara anggota ASEAN. Sedangkan rerata skor tertinggi diperoleh oleh aspek toleransi dengan nilai 3,35. Hal tersebut mengindikasikan kelemahan respect about human right and value Mahasiswa Akuntansi UNY berada pada aspek pengetahuan budaya negara anggota ASEAN lainnya.

Analysis competency meliputi empat indikator yaitu kemampuan berbahasa Inggris, berbahsa ASEAN, penguasaan teknologi dan penguasaan perangkat lunak akuntansi. Kategorisasi mean ideal dan standar deviasi ideal terkait kesiapan kerja mahasiswa akuntansi dilihat dari analysis competency yang dimiliki mahasiswa akuntansi Universitas Negeri Yogyakarta adalah sebagai berikut:

Tabel 15. Kecenderungan Analysis Competency Mahasiswa Program Studi Akuntansi UNY

\begin{tabular}{llrc}
\hline No & Kategori & Rentang & Jumlah \\
\hline $\mathbf{1}$ & Sangat Siap & $\geq 26$ & 0 \\
\hline $\mathbf{2}$ & Siap & $20-25$ & 112 \\
\hline $\mathbf{3}$ & Kurang & $14-19$ & 50 \\
& Siap & & \\
\hline $\mathbf{4}$ & Sangat & $<14$ & 10 \\
& Tidak Siap & & \\
\hline
\end{tabular}

Berdasarkan tabel di atas dapat disimpulkan bahwa sebagian besar $(69,14 \%)$ Mahasiswa Program Studi Akuntansi UNY merasa siap dan yang merasa kurang siap sebanyak 30,86\%. Berdasarkan analysis competency yang dimiliki, tidak ada Mahasiswa Program Studi Akuntansi Universitas Negeri Yogyakarta yang merasa sangat tidak siap terhadap masyarakat ekonomi ASEAN. Deskripsi data tersebut dapat dilihat dengan lebih rinci pada gambar 6 berikut: 
JURNAL NOMINAL / VOLUME V NOMOR 1 / TAHUN 2016

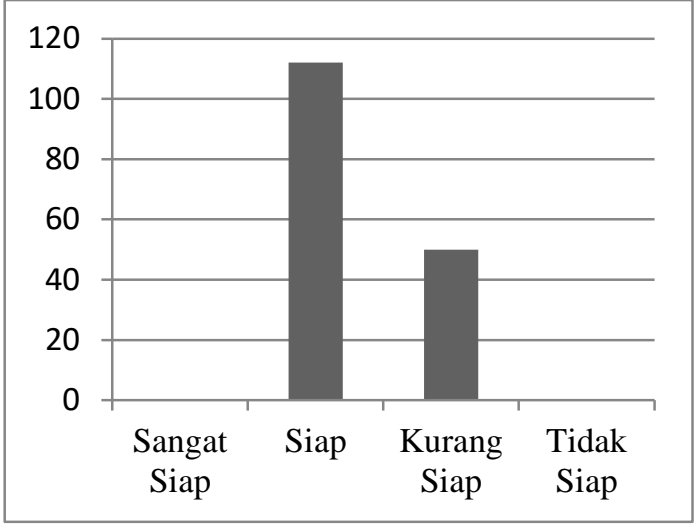

Gambar 6. Diagram Batang Kecenderungan Analysis Competency Mahasiswa Akuntansi UNY

Berdasarkan gambar di atas dapat disimpulkan bahwa sebagian besar $(69,14 \%)$ mahasiswa merasa siap dan mahasiswa yang merasa kurang siap sebanyak 30,86\%. Sehingga berdasarkan kompetensi analisis yang dimiliki tidak ada mahasiswa Akuntansi Universitas Negeri Yogyakarta yang merasa sangat tidak siap terhadap masyarakat ekonomi ASEAN.

Tabel 16. Perbandingan Mean dan Standar Deviasi Masing-Masing Indikator Analysis Competency

\begin{tabular}{ccc}
\hline Kompetensi & $\begin{array}{c}\text { Mean } \\
\text { (Rerata) }\end{array}$ & $\begin{array}{c}\text { Ran } \\
\text { king }\end{array}$ \\
\hline Analysis competency & 2,58 & \\
\hline Kemampuan & 2,32 & 3 \\
berbahasa Inggris & & \\
\hline $\begin{array}{l}\text { Kemamuan } \\
\text { berbahasa negara } \\
\text { anggota ASEAN }\end{array}$ & 2,14 & 4 \\
\end{tabular}

\begin{tabular}{lcc}
\hline $\begin{array}{l}\text { Penguasaan } \\
\text { teknologi }\end{array}$ & 3,09 & 1 \\
komunikasi & & \\
\hline $\begin{array}{l}\text { Penguasaan } \\
\text { perangkat lunak }\end{array}$ & 2,71 & 2 \\
akuntansi & & \\
\end{tabular}

Aspek analysis competency diukur melalui empat aspek. Rerata skor terendah yakni 2,14 diperoleh oleh aspek kemampuan berbahasa negara anggota ASEAN. Hal tersebut mengindikasikan aspek kemampuan berbahasa asing mahasiswa akuntansi perlu ditingkatkan lagi. Sedangkan rerata skor tertinggi diperoleh oleh aspek toleransi dengan nilai 3,09. Sedangkan rerata skor secara keseluruhan yakni 2,58.

Hasil penelitian menunjukkan bahwa Kesiapan Kerja Mahasiswa Program Studi Akuntansi UNY dalam kategori siap. Walau begitu, berdasarkan kuesioner yang dibagikan kepada Mahasiswa Program Studi Akuntansi UNY dapat di lihat bahwa terdapat beberapa aspek yang dinilai sangat siap, diantaranya ethical competency dan respect about human right and value.

Berdasarkan 162 kuesioner terhadap 8 item pernyataan tentang ethical competency terdapat 41 responden yang paling banyak menyatakan sangat siap. Apabila ditelusuri ke dalam empat aspek pada ethical competency maka Mahasiswa Program Studi Akuntansi UNY paling banyak merasa 


\section{JURNAL NOMINAL / VOLUME V NOMOR 1 / TAHUN 2016}

sangat siap pada aspek moral dan etika. Hal tersebut dibuktikan dengan 48 Mahasiswa Program Studi Akuntansi UNY atau 29,62\% sampel menjawab sangat setuju pada item pernyataan kuesioner nomor satu yang menyatakan "Saya berusaha mematuhi dan melaksanakan kode etik akuntan dan peraturan perundang-undangan yang berlaku."

Selain itu sebanyak 36 Mahasiswa Program Studi Akuntansi UNY menyatakan sangat setuju pada pernyataan item 3 . Item pernyataan nomor 3 menyatakan bahwa "Dalam melaksanakan tugas kuliah, saya berusaha selalu tepat waktu" yang artinya Mahasiswa Program Studi Akuntansi Universitas Negeri Yogyakarta telah memiliki tanggung jawab pada tugas atau kewajibannya.

Terdapat sebanyak 36 Mahasiswa Program Studi Akuntansi UNY yang paling banyak menyatakan sangat setuju pada item no. 1 bahwa "Saya selalu memberikan kemampuan terbaik dalam setiap tugas kuliah dan organisasi." Sebanyak 35 Mahasiswa Program Studi Akuntansi UNY yang paling banyak menyatakan setuju pada item no. 2 bahwa "Saya selalu berfikir positif dalam menghadapi kesukaran saat mengerjakan tugas." Dengan demikian dapat disimpulkan Mahasiswa Program Studi Akuntansi Universitas Negeri Yogyakarta mempunyai kepedulian pada nilai dan hak manusia utamanya pada aspek kebahagiaan kerja.

Sebanyak 64 Mahasiswa Program Studi Akuntansi UNY atau 39,5\% sampel menyatakan sangat setuju pada item nomor 8 yang menyatakan "Saya menghargai hak teman atau rekan untuk beribadah sesuai dengan agama masing-masing." Selain itu sebanyak 54 Mahasiswa Program Studi Akuntansi UNY menyatakan setuju pada item pernyataan no.7 bahwa "Saya menghormati perbedaan suku dan ras pada rekan dan orang di sekitar saya." Kesimpulan yang dapat ditarik yaitu Mahasiswa Program Studi Akuntansi Universitas Negeri Yogyakarta telah mempunyai toleransi yang merupakan salah satu bentuk kepedulian pada nilai dan hak manusia.

Secara umum Kesiapan Kerja Mahasiswa Program Studi Akuntansi UNY berada pada kategori siap. Hal tersebut dibuktikan dengan rerata skor yang mencapai 2,79. Selain itu tiga dari lima kompetensi yang dijadikan indikator pengukur Kesiapan Kerja Mahasiswa Program Studi Akuntansi Universitas Negeri Yogyakarta memiliki rerata skor pada kondisi siap. Secara lebih rinci berikut indikator Kesiapan Kerja Mahasiswa Program Studi Akuntansi Universitas Negeri Yogyakarta yang berada pada kondisi siap yaitu knowledge competency, capability competency dan analysis competency. 


\section{JURNAL NOMINAL / VOLUME V NOMOR 1 / TAHUN 2016}

Kompetensi pengetahuan yang meliputi kompetensi-kompetensi pengetahuan IFRS, profesi akuntan, MEA, serta manajemen perubahan sudah pada posisi siap. Hal tersebut dibuktikan dengan dari delapan pernyataan, sebanyak tujuh item mendapat respon setuju dari lebih dari $50 \%$ responden.

Terdapat sebanyak 124 Mahasiswa Program Studi Akuntansi UNY yang paling banyak menyatakan sangat setuju pada item nomor 8 bahwa "Saya memahami risiko akibat berbagai peraturan di era Masyarakat Ekonomi ASEAN.” Sebanyak 116 Mahasiswa Program Studi Akuntansi UNY yang paling banyak menyatakan setuju pada item nomor 1 bahwa "Saya mampu menyusun laporan keuangan dengan menggunakan standar dari International Financial Reporting Standart." Kesimpulan yang dapat ditarik yaitu Mahasiswa Program Studi Akuntansi Universitas Negeri Yogyakarta memiliki Kesiapan Kerja pada kondisi siap berdasarkan kompetensi pengetahuan yang dimiliki.

Terdapat sebanyak 130 Mahasiswa Program Studi Akuntansi UNY yang paling banyak menyatakan setuju pada item no. 2 bahwa "Saya yakin dapat memperoleh pekerjaan sesuai keinginan walaupun harus bersaing dengan lulusan S1 dari negara ASEAN lain" dan pada item no. 4 bahwa "Saya mampu melakukan negosiasi dalam kehidupan sehari-hari." Dengan demikian dapat disimpulkan Mahasiswa Program Studi Akuntansi Universitas Negeri Yogyakarta telah mempunyai pengetahuan tentang persaingan akuntan di ASEAN dan keahlian negosiasi.

Kesiapan Kerja Mahasiswa Program Studi Akuntansi UNY ditinjau dari capability competency dibuktikan dengan dari sembilan pernyataan, sebanyak enam item mendapat respon setuju dari lebih dari 50\% responden. Sehingga dapat ditarik kesimpulan Mahasiswa Program Studi Akuntansi Universitas Negeri Yogyakarta diukur dari kemampuan yang dimiliki memiliki Kesiapan Kerja pada kondisi siap.

Sebanyak 127 Mahasiswa Program Studi Akuntansi UNY atau 78,39\% sampel yang paling banyak menyatakan setuju pada item no. 5 bahwa "Saya mampu berkomunikasi dengan menggunakan akun social media." Sebanyak 122 Mahasiswa Program Studi Akuntansi UNY yang paling banyak menyatakan setuju pada item no. 4 bahwa "Saya hanya dapat berkomunikasi dalam Bahasa Indonesia dan Bahasa Inggris". Dengan demikian dapat disimpulkan Mahasiswa Program Studi Akuntansi Universitas Negeri Yogyakarta telah menguasai teknologi untuk berkomunikasi namun belum dapat berkomunikasi dalam bahasa ASEAN lainya. Kesimpulan yang dapat ditarik yaitu Mahasiswa Program Studi Akuntansi Universitas Negeri Yogyakarta diukur dari 


\section{JURNAL NOMINAL / VOLUME V NOMOR 1 / TAHUN 2016}

kompetensi analisis mempunyai Kesiapan Kerja pada kondisi siap.

Perbandingan mean dan standar deviasi dari seluruh indikator dilakukan untuk mengetahui aspek mana yang mendapat skor terendah dan tertinggi. Berdasarkan hal tersebut, dapat ditelusuri poin-poin yang menjadi kelemahan ataupun keunggulan dari kompetensi yang dimiliki mahasiswa Akuntansi Universitas Negeri Yogyakarta.

Hasil perbandingan seluruh skor antar indikator menunjukan apabila skor tertinggi diperoleh pada aspek toleransi, disusul moral etika dan kebahagiaan kerja. Hasil tersebut mengindikasikan apabila mahasiswa akuntansi Universitas Negeri Yogyakarta telah memiliki kompetensi unggulan berupa toleransi, moral etika dan kebahagiaan kerja. Hal tersebut sesuai dengan tujuan Universitas Negeri Yogyakarta yang berusaha menciptakan mahasiswa yang taqwa, mandiri dan cendekia.

Aspek-aspek yang memiliki jumlah skor dan rata-rata terendah diantaranya kemampuan berbahasa negara anggota ASEAN lainya dan berbahasa Inggris, persepsi isu politik dan persepsi mengenai standar akuntansi di berbagai negara ASEAN. Hal tersebut mengindikasikan ketiga aspek tersebut perlu menjadi perhatian bagi pihak terkait manajemen pendidikan prodi Akuntansi Universitas Negeri Yogyakarta agar segera dapat diambil langkah perbaikan. Sedangkan ditinjau dari rata-rata agregat seluruh aspek, Kesiapan Kerja mendapat skor 2,79.

Hasil penelitian ini sejalan dengan hasil penelitian sebelumnya yang dilakukan oleh Muttanachai Suttipun dimana mahasiswa akuntansi telah memiliki Kesiapan Kerja pada kategori siap dalam menghadapi era Masyarakat Ekonomi ASEAN. Selain itu kelemahan mahasiswa akuntansi dalam menghadapi era Masyarakat Ekonomi ASEAN juga tidak mengalami perbedaan hasil dengan penelitian sebelumnya dimana kompetensi dengan skor terendah terdapat pada kemampuan berkomunikasi dengan bahasa negara-negara ASEAN dan bahasa Inggris.

\section{SIMPULAN DAN SARAN}

\section{Simpulan}

Kesiapan kerja mahasiswa Akuntansi Universitas Negeri Yogyakarta yang ditinjau dari kompetensi dapat disimpulkan sebagai berikut: pertama, Kesiapan kerja mahasiswa Akuntansi Universitas Negeri Yogyakarta ditinjau dari aspek ethical competency termasuk dalam kategori siap, dengan pencapaian persentase sebesar $73,46 \%$. Sebanyak 25,31\% mahasiswa Akuntansi Universitas Negeri Yogyakarta pada kategori sangat siap dan hanya $1,23 \%$ yang masuk dalam kategori kurang siap. Hal tersebut berarti sebagian besar mahasiswa mempunyai Kesiapan Kerja ditinjau dari kompetensi etika pada kategori siap. 


\section{JURNAL NOMINAL / VOLUME V NOMOR 1 / TAHUN 2016}

Kedua, Kesiapan kerja mahasiswa Akuntansi Universitas Negeri Yogyakarta ditinjau dari aspek knowledge competency termasuk dalam kategori siap, dengan pencapaian persentase sebesar $75,93 \%$. Terdapat $20,37 \%$ mahasiswa yang berada pada kategori kurang siap. Namun, dapat ditarik kesimpulan sebagian besar mahasiswa mempunyai Kesiapan Kerja ditinjau dari kompetensi pengetahuan pada kategori siap.

Ketiga, Kesiapan kerja ditinjau dari aspek capability competency mahasiswa termasuk dalam kategori siap dengan pencapaian persentase sebesar $59,26 \%$ sedangkan yang kurang siap sebesar 38,27\%. Hal tersebut menandakan sebagian besar siswa mempunyai Kesiapan Kerja ditinjau dari capability competency pada kategori siap.

Keempat, Kesiapan kerja ditinjau dari aspek respect about human right and value mahasiswa termasuk dalam kategori sangat siap, dengan pencapaian persentase sebesar 30,86\% dan kategori siap 67,9\%. Berdsarkan hal tersebut dapat ditarik kesimpulan sebagian besar mahasiswa akuntansi UNY mempunyai Kesiapan Kerja ditinjau dari respect about human right and value pada kategori siap.

Kesiapan kerja ditinjau dari aspek analysis competency mahasiswa termasuk dalam siap, dengan pencapaian persentase sebesar $69,14 \%$ dan hanya $30,86 \%$ yang masuk kategori kurang siap. Hal tersebut menandakan mahasiswa Akuntansi Universitas Negeri Yogyakarta mempunyai Kesiapan Kerja ditinjau dari analysis competency pada kategori siap.

\section{Saran}

Berdasarkan hasil penelitian di atas dapat disampaikan saran sebagai berikut disarankan kepada peneliti selanjutnya untuk mengungkap lebih jauh Kesiapan Kerja mahasiswa Akuntansi Universitas Negeri Yogyakarta dengan penggunaan teknik pengumpulan data yang berupa tes. Selain itu disarankan kepada peneliti selanjutnya untuk mengungkap lebih jauh Kesiapan Kerja mahasiswa Akuntansi Universitas Negeri Yogyakarta dengan menggunakan indikator lain yang diduga mempengaruhi Kesiapan Kerja mahasiswa, sehingga dapat memperluas cakupan kompetensi yang dievaluasi.

Berdasarkan hasil penelitian diharapkan lembaga pendidikan yang menyelenggarakan program studi akuntansi lebih mendorong dan memotivasi mahasiswa agar meningkatkan kemampuan berbahasa asing, persepsi politik dan standar akuntansi internasional. Selain itu aspek kompetensi yang sudah bagus seperti toleransi, moral etika dan kebahagiaan kerja perlu dipertahankan. Sedangkan kepada para mahasiswa program studi Akuntansi UNY untuk terus meningkatkan kompetensikompetensi yang diperlukan untuk 


\section{JURNAL NOMINAL / VOLUME V NOMOR 1 / TAHUN 2016}

memasuki dunia kerja, seperti: capability competency dan analysis competency.

\section{DAFTAR PUSTAKA}

BPS. (2013). Pengangguran Terbuka Menurut Pendidikan Tertinggi yang Ditamatkan 2004-2013. Diambil dari: http://www.bps.go.id/publications/pub likasi.php, pada tanggal 31 Mei 2014, Jam 15.35 WIB

Departemen Perdagangan. (2012). Мепији ASEAN Economic Community 2015. Departemen Perdagangan Republik Indonesia.

Hair, J.F., Anderson, R.E., Tatham, R.L. \& Black, W.C. (2006). Multivariate Data Analysis, Sixth Edition, Prentice Hall International: UK.

Imam Ghozali. (2011). Aplikasi Analisis Multivariate Dengan Program IBM SPSS 19. Semarang: Badan Penerbit Universitas Diponegoro.

Ikatan Akuntan Indonesia (IAI). (2014). "Bersiap Diri Menyambut Pasar Tunggal ASEAN". Diakses melalui http://www.iaiglobal.or.id pada tanggal 23 Mei 2015, Jam 11.05 WIB.

Sugiyono. (2010). Statistika untuk Penelitian. Bandung: Alfabeta

Suharsimi Arikunto. (2013). Prosedur Penelitian Untuk Pendekatan Praktik. Jakarta: Rineka Cipta.
Sutrisno Hadi. (2001). Statistik Jilid II. Yogyakarta: Andi Offset.

Suttipun, Muttanachai. (2014). "The Readiness of Thai Accounting Students for the ASEAN Economic Community: An Exploratory Study.” Asian Journal of Business and Accounting. 7(2). Hlm. 139-157

Wirawan. (2012). Evaluasi Teori, Model, Standar, Aplikasi, dan Profesi. Depok: PT.Raja Grafindo Persada 